\title{
Phytophagous insects of giant hogweed Heracleum mantegazzianum (Apiaceae) in invaded areas of Europe and in its native area of the Caucasus
}

\author{
Steen Ole HANSEN ${ }^{1}, J_{\text {An HATtendORF }}^{1}$, Ruediger WITTENBERG ${ }^{2}$, Sergey Ya. REZNIK ${ }^{3}$, Charlotte \\ NIELSEN ${ }^{4}$, Hans Peter RAVN ${ }^{4}$ and Wolfgang NENTWIG ${ }^{1 *}$ \\ ${ }^{1}$ Zoological Institute, University of Bern, Baltzerstrasse 6, 3012 Bern, Switzerland \\ ${ }^{2}$ CABI Bioscience Switzerland Centre, Rue des Grillons 1, 2800 Delémont, Switzerland \\ ${ }^{3}$ Zoological Institute, Russian Academy of Science, 199034 St. Petersburg, Russia \\ ${ }^{4}$ Danish Forest and Landscape Research Institute, Hoersholm Kongevej 11, 2970 Hoersholm, Denmark
}

\begin{abstract}
Key words. Biological control, enemy release hypothesis ERH, evolution of increased competitive ability EICA, invasive weed, monophagous herbivores, non indigenous species, phytophagous insects

Abstract. Giant hogweed, Heracleum mantegazzianum (Apiaceae), was introduced from the Caucasus into Western Europe more than 150 years ago and later became an invasive weed which created major problems for European authorities. Phytophagous insects were collected in the native range of the giant hogweed (Caucasus) and were compared to those found on plants in the invaded parts of Europe. The list of herbivores was compiled from surveys of 27 localities in nine countries during two seasons. In addition, literature records for herbivores were analysed for a total of 16 Heracleum species. We recorded a total of 265 herbivorous insects on Heracleum species and we analysed them to describe the herbivore assemblages, locate vacant niches, and identify the most hostspecific herbivores on $H$. mantegazzianum. When combining our investigations with similar studies of herbivores on other invasive weeds, all studies show a higher proportion of specialist herbivores in the native habitats compared to the invaded areas, supporting the "enemy release hypothesis" (ERH). When analysing the relative size of the niches (measured as plant organ biomass), we found less herbivore species per biomass on the stem and roots, and more on the leaves (Fig. 5). Most herbivores were polyphagous generalists, some were found to be oligophagous (feeding within the same family of host plants) and a few had only Heracleum species as host plants (monophagous). None were known to feed exclusively on $H$. mantegazzianum. The oligophagous herbivores were restricted to a few taxonomic groups, especially within the Hemiptera, and were particularly abundant on this weed.
\end{abstract}

\section{INTRODUCTION}

\section{Weed invasion hypotheses}

The increased competitive ability of non-indigenous plant species is often attributed to the absence of their specialized natural enemies (Torchin et al., 2001; Mitchell \& Power, 2003). In this paper we investigate the herbivores of giant hogweed with three main goals. First, we seek to test the hypothesis that proportionally more species of herbivore specialists are found in the native range of $H$. mantegazzianum. Additionally, this will provide a list of associated herbivores and their host range that can be considered in developing a classical biological control programme. Second, we examine if certain orders of herbivorous insecs have a higher representation in the native region compared with the invaded region. Third, we evaluate the niche size (measured as plant organ weight) of $H$. mantegazzianum and investigate whether any parts are less occupied within the introduced range, making them suitable targets for biological control. These three questions are relevant when discussing why some plants transform into serious weeds in regions to which they have been introduced.

Several invasion hypotheses have been suggested. The enemy release hypothesis (ERH) (Keane \& Crawley, 2002; Colautti et al., 2004) predicts that top down regula- tion of the population (by predators, parasites, pathogens etc) will be lower in the range of introduction. The plant will experience less damage by herbivores than the competing vegetation, thus gaining a competitive advantage when no effective antagonists have yet followed the weed into the invaded region. The evolution of increased competitive ability hypothesis (EICA) (Blossey \& Nötzold, 1995; Müller-Schärer et al., 2004) posits that a plant invests significant resources into the defence against herbivores in its indigenous environment. The ability of the non-indigenous weed to allocate these defence resources into growth increases its fitness in the invaded region and it may subsequently become invasive (Pyšek, 1994; Pyšek \& Pyšek, 1995). In many European countries H. mantegazzianum has reached invasive stages IV or $\mathrm{V}$, on a scale from I to $\mathrm{V}$, as created by Colautti \& MacIsaacs (2004). Both hypotheses predict that insects or pathogens do not regulate a weed in the invaded area as well as in its native range (Memmott et al., 2000). This may also be the case if the number or abundance of specialized herbivore species is lower in the invaded area.

In this paper we want to test the first hypothesis; that is to investigate if there is, generally, a larger proportion of specialist herbivores in the native region. We will compare the result with other studies on invasive weeds. This hypothesis has rarely been tested, although Mitchell \&

\footnotetext{
* Author for correspondence; e-mail: wolfgang.nentwig@zos.unibe.ch
} 
Power (2003) demonstrated that the invasiveness of some weeds is correlated with a release from pathogens. Memmott et al. (2000) demonstrated that the biomass of specialist herbivores was higher in the native range of their plant hosts. Wolfe (2002) confirmed a higher level of attack by herbivores and pathogens on white campion (Silene latifolia, Caryophyllaceae) in its native range.

Plants continuously develop specific systems of antifeeding defences such as secondary metabolites, sap containing few nutrients, trichomes, thick epidermes etc. Some plant defence systems are particularly effective against certain insect guilds. Accordingly, we also investigate in this study whether insects from certain orders of insects feed specifically on this plant. Since the insect orders are not equally represented, it is necessary to compare the number of species on $H$. mantegazzianum with the average (expected) frequency of the herbivore guild. Therefore we choose to compare it, on the one hand, with the world distribution of herbivores and, on the other, with their distribution in the former USSR.

\section{Giant hogweed}

The area of origin hypothesis assumes that the number of congeneric weed relatives and the number of specialized herbivores is highest in the evolutionary centre of a given species (Nentwig et al., 2004). It is generally accepted that the centre of origin of the genus Heracleum is in the Caucasus region, where more than 12 Heracleum species and many subspecies have been described, whereas in central Europe only two indigenous and three alien species occur. Heracleum mantegazzianum Sommier and Levier (Apiaceae) is native to the western Caucasus where it occurs in the upper forest belt, mainly in meadows, clearings, and forest margins (Mandenova, 1950). Spatially separated by regions with dryer climate the plant only reached Western Europe after it was introduced to botanical gardens in the $19^{\text {th }}$ century (Pyšek, 1994). Meanwhile it has naturalized along waterways and roads and on fallow and disturbed land all over Europe. Its good competitive ability and high seed production makes it an aggressive invasive species causing problems for many European authorities (Schepker \& Kowarik 2001), especially in regions where the land use is changing. It is a typical representative of the competitive/ruderal strategy type (Otte \& Franke, 1998). There are two main reasons to stop this weed from spreading further in Europe (1) the plant affects the structure and function of ecosystems by reducing the biodiversity of communities and landscapes (Pyšek \& Pyšek, 1995) and (2) the plant is a toxic nuisance to the public because its sap causes a serious UV-induced phytodermatitis (Otte \& Franke, 1998).

H. mantegazzianum has at least two defence systems against herbivores. The first is a chemical defence system based on furanocoumarins (Berenbaum \& Feeny, 1981), which are found in all plant organs at high concentrations (Knudsen, 1983). This defence acts against both internal and external feeders. Second, the plants have rows of hairs of varying lengths $(1 \mu \mathrm{m}-7 \mathrm{~mm})$ on leaf edges, leaf veins, and on the stem (Hansen, 2005). This defence mechanism acts against external feeders and internally ovipositing females. Both systems may influence the numbers of herbivore species on the plant mainly by deterring generalist herbivores from feeding (Lawton, 1976).

To compare the degree of vacancy of a niche it is necessary to define the niche and niche sizes. Since phytophagous insects are predominantly specialised in feeding on certain plant organs (leaves, roots, stem, and umbels in the case of Heracleum spp.) the biomass of these organ can be used to define the size of the niche which may potentially be occupied by herbivores (Nentwig et al., 2004). Organs with more biomass can potentially support the development of more herbivores, although other factors such as the palatability of the plant tissue, seasonal growth patterns, changes in nutrients and the biotic and abiotic surroundings also are important for determining the number of herbivores (species and individuals) the organ can support (Strong et al., 1984).

In this study we wish to test the following three hypotheses: (1) more specialist herbivore species are found on $H$. mantegazzianum in its native range compared with the invaded regions, and this is also the case for other similarly invasive weeds; (2) certain insect orders are more abundant on $H$. mantegazzianum in the native compared with the invaded area; and, (3) the biomass of the plant organs is not a suitable measurement for predicting the number of species that feeds on each plant organ of $H$. mantegazzianum.

\section{MATERIAL AND METHODS}

\section{Study areas}

The field surveys were carried out in Belgium, the Czech Republic, Denmark, Germany, the Netherlands, Latvia, Switzerland, and in the Caucasian areas of Georgia and Russia. In the period from early May to September 2002 until May to mid of August 2003, data from 37 different locations were acquired, 21 localities in Europe and 16 in the western Caucasus up to 2050 $\mathrm{m}$ a.s.l., which is considered to be the native region of this plant (Mandenova, 1950; Otte \& Franke, 1998). An approximately equal amount of time was spent collecting insects in each region.

\section{Insect collection and data analysis}

We investigated ten plants per location and visited many of these locations more than once during the two seasons. We searched the leaf surface, stem, and umbel with aspirator and forceps. After this, we dissected the stem and petioles to uncover internal stem feeders. Finally we excavated the root and sliced it carefully to find external and internal root borers. We reared larvae to adult stages in climatic chambers to allow identification.

Specialists from the Natural History Museum of London Identification Service verified some species identifications. The species list was enhanced with information from the literature about (a) host plant range, (b) herbivore distribution, (c) plant organs damaged by larvae or adults and (d) how the insects feed on the plant. Different authors define the terms monophagous, oligophagous and polyphagous differently (e.g. Memmot et al., 2000; Imura, 2003). We adopted the following definitions. A herbivore is monophagous if it is feeding on just one plant genus (Heracleum), it is oligophagous if it is restricted to one family (Apiaceae), and it is polyphagous if it is feeding on different 
families. We define the host specificity of dioecious aphids by the range of their secondary hosts, because the herbivore damage to the primary host is usually insignificant.

Data from previous large-scale investigations of herbivores on H. mantegazzianum in England, Switzerland and Slovakia (Sampson, 1990; Bürki \& Nentwig, 1997; Cagán \& Nentwig, 1998) supplemented our data and are included in this study. Additionally we gathered the scattered information from 161 publications and various insect keys containing species information from Europe and the Caucasus. To obtain information about Caucasian insect species we evaluated the Russian literature closely. By combining all known information from the available literature we could approximate the host range of the insects we encountered. No experiments were performed to verify such host ranges. We consulted three other publications that analysed the insect fauna on weed populations in both native and invaded areas, while also presenting information on the feeding specificity of the herbivores (Jobin et al., 1996; Memmott et al., 2000; Imura, 2003). In many ways the species of weeds studied by these authors were similar to giant hogweed (well investigated, perennial, dicotyledonous weeds, forming long-living stands, with a serious impact on invaded habitats) and therefore they are suitable for comparison with our own data.

\section{Niche}

To obtain a measurement of the niche size, the fresh biomass of the plant organs (leaves, root, stem, and umbels) was determined for 78 plants in the flowering stage (three years old) and for 64 plants in the vegetative stage (approximately two to three years old). We did not analyze seedlings. Plants were chosen equally from two localities in the Russian Caucasus and four localities in Mariánské Lázně in the Czech Republic in the period from mid-July until mid-August 2003.

\section{Statistical analysis}

To test for difference in the proportion of specialists among the different weed species and in the native or the invaded region (Fig. 2) we employed a $2 \times 2 \times 4$ contingency test for partial independence. A comparison of each insect order on $H$. mantegazzianum in the different regions was carried out with 2 $\times 6$ contingency tests. After that the comparison of each insect order on H. mantegazzianum in the different regions was compared with worldwide herbivore species and the herbivore species within the former USSR (Fig. 3). This was carried out using $2 \times 2$ contingency tests applied several times and, subsequently, adjusting for the multiple comparisons using Bonferroni corrections (Howell \& Games, 1974). The niche size (organ biomass) was compared with the proportion of species for each region (Fig. 5) using a two-tailed t-test. The proportion of species in the native and invaded regions were compared for each of the plant organs (Fig. 5) by means of a $2 \times 2$ contingency test, with Bonferroni corrections for multiple comparisons.

\section{RESULTS}

\section{Insect species}

Overall, we gathered information on 358 insect species occurring on 16 different Heracleum species. Of these insects, 265 were herbivores and were used in the analyses presented here. About 162 species were herbivores on $H$. mantegazzianum, of which 123 were polyphagous or had unknown levels of specificity. These are omitted from Table 1 but have been included in the analyses. The remaining 39 monophagous and oligophagous herbivore species are presented in Table 1. They belong to four orders: Hemiptera ( 8 aphid species, 4 spe-

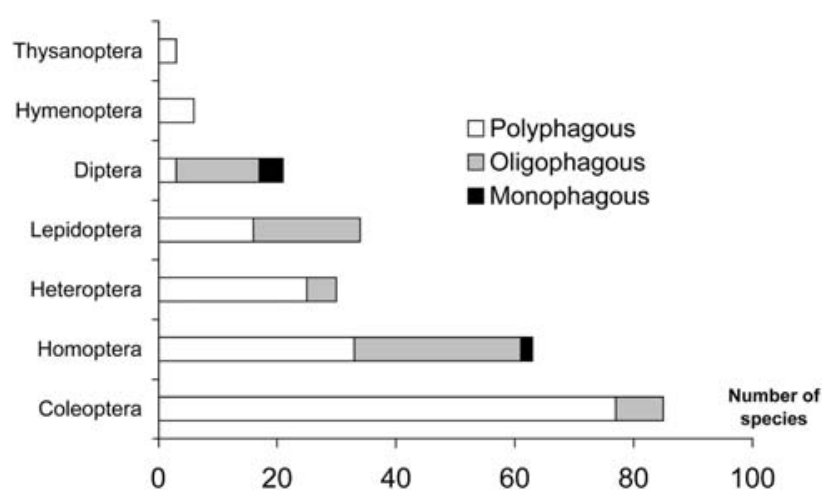

Fig. 1. Taxonomic origin of 265 herbivorous species found on Heracleum spp. Most species are polyphagous. Oligophagous herbivores are restricted to five taxonomic groups, monophagous species are only found in Hemiptera and Diptera.

cies of Heteroptera), Coleoptera (9 species of which 6 are curculionids), Lepidoptera (8 moths), and Diptera (10 species of which 5 are agromyzids). Among these species, the following oligophagous species were the most abundant in the examined regions: Anuraphis subterranea, Cavariella spp., Lixus iridis, Agonopterix caucasiella, Depressaria radiella and Melanagromyza heracleana. The occasionally abundant monophagous aphid Paramyzus heraclei transmitted yellow spots to the plant, possibly due to a virus infection. As far as the available information on host plants shows, none of the herbivores was feeding exclusively on $H$. mantegazzianum.

The taxonomic distribution of 265 herbivorous insects in the genus Heracleum is shown in Fig. 1. Two thirds of all species belong to Hemiptera or Coleoptera but monophagous species are so far only found in Hemiptera or Diptera.

We analysed three variables for partial independence (specialist vs generalist, invasive vs native, $H$. mantegazzianum or $S$. carolinense or $S$. altissima or $C$.

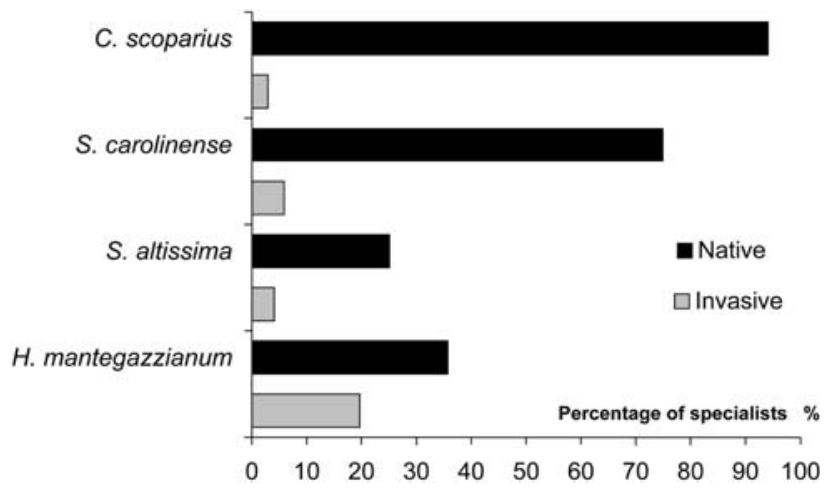

Fig. 2. Specialist herbivore species on invasive weeds make up a significantly higher proportion of the herbivores in the native areas compared with the invaded areas $(p<0.001)$ and are significantly different for each of the three invasive weed species $(\mathrm{p}<0.001)$. Data for goldenrod Solidago altissima $\mathrm{L}$. obtained from Jobin et al. $(1996, \mathrm{n}=276)$, data for horsenettle Solanum carolinense L. from Imura $(2003, \mathrm{n}=57)$, and data for broom Cytisus scoparius L. from Memmott et al. $(2000, \mathrm{n}=42)$. 
TABLE 1. Monophagous and oligophagous herbivore species from H. mantegazzianum in Europe and in the Caucasus.

\begin{tabular}{|c|c|c|c|c|c|c|}
\hline & $\begin{array}{c}\text { Feeding } \\
\text { specificity }\end{array}$ & $\begin{array}{c}\text { Stage } \\
\text { collected }^{\mathrm{a}}\end{array}$ & Way of feeding ${ }^{\mathrm{b}}$ & Plant organ ${ }^{c}$ & Locality $^{\mathrm{d}}$ & Source \\
\hline \multicolumn{7}{|l|}{ HEMIPTERA } \\
\hline \multicolumn{7}{|l|}{ Pentatomidae } \\
\hline Graphosoma lineatum L. & oligo & $\mathrm{L} / \mathrm{A}$ & sap sucker & umbel & $\mathrm{EU} / \mathrm{CAU}$ & $\begin{array}{l}\text { Wagner, 1966; Jakob et al., 1998; Hansen \& } \\
\text { Hattendorf }^{\text {f }}\end{array}$ \\
\hline \multicolumn{7}{|l|}{ MIRIDAE } \\
\hline Orthops basalis Costa & oligo & A & sap sucker & $\begin{array}{l}\text { stem, umbel, } \\
\text { leaves }\end{array}$ & $\mathrm{EU}^{\mathrm{OC}}$ & Sampson, 1990; Nielsen \& Ravn ${ }^{\mathrm{f}}$ \\
\hline Orthops campestris L. & oligo & $\mathrm{L} / \mathrm{A}$ & sap sucker & stem, umbel & $\mathrm{EU}^{\mathrm{OC}}$ & $\begin{array}{l}\text { Grace \& Nelson, 1981; Bürki \& Nentwig, } \\
\text { 1997; Hansen \& Hattendorf }{ }^{\text {f }}\end{array}$ \\
\hline Orthops kalmii L. & oligo & A & sap sucker & stem, umbel & $\mathrm{EU}^{\mathrm{OC}}$ & $\begin{array}{l}\text { Bürki \& Nentwig, 1997; Jakob et al., 1998; } \\
\text { Nielsen \& Ravn }\end{array}$ \\
\hline \multicolumn{7}{|r|}{ 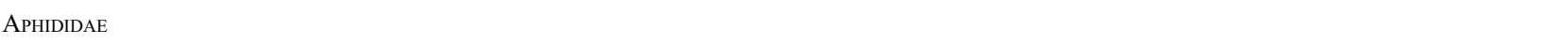 } \\
\hline Anuraphis subterranea Walker & oligo & $\mathrm{L} / \mathrm{A}$ & sap sucker & leaf envelope & $\mathrm{EU} / \mathrm{CAU}$ & Bürki \& Nentwig, 1997; Hansen \& Hattendorf ${ }^{\mathrm{f}}$ \\
\hline Cavariella aegopodii Scopoli & oligo & $\mathrm{L} / \mathrm{A}$ & $\begin{array}{l}\text { disease transmit- } \\
\text { ter, sap sucker }\end{array}$ & $\begin{array}{l}\text { stem, umbel, } \\
\text { leaves }\end{array}$ & EU/CAU & $\begin{array}{l}\text { Holman, 1991; Sampson, 1990; Nielsen \& } \\
\operatorname{Ravn}^{f}\end{array}$ \\
\hline $\begin{array}{l}\text { Cavariella aquatica } \text { Gillette \& } \\
\text { Bragg }\end{array}$ & oligo & $\mathrm{L} / \mathrm{A}$ & sap sucker & $\begin{array}{l}\text { stem, umbel, } \\
\text { leaves }\end{array}$ & CAU & Hansen \& Hattendorf ${ }^{\mathrm{f}}$ \\
\hline Cavariella pastinacea $\mathrm{L}$. & oligo & $\mathrm{L} / \mathrm{A}$ & $\begin{array}{l}\text { disease transmit- } \\
\text { ter, sap sucker }\end{array}$ & $\begin{array}{l}\text { stem, umbel, } \\
\text { leaves }\end{array}$ & $\mathrm{EU} / \mathrm{CAU}$ & $\begin{array}{l}\text { Sampson, 1990; Holman, 1991; Bürki \& } \\
\text { Nentwig, 1997; Hansen \& Hattendorf }{ }^{f}\end{array}$ \\
\hline $\begin{array}{l}\text { Cavariella theobaldi Gillette \& } \\
\quad \text { Bragg }\end{array}$ & oligo & $\mathrm{L} / \mathrm{A}$ & $\begin{array}{l}\text { disease transmit- } \\
\text { ter, sap sucker }\end{array}$ & $\begin{array}{l}\text { stem, umbel, } \\
\text { leaves }\end{array}$ & $\mathrm{EU} / \mathrm{CAU}$ & $\begin{array}{l}\text { Sampson, 1990; Nielsen \& Ravn }{ }^{\text {f }} \text {; Hansen \& } \\
\text { Hattendorf }^{\text {f }}\end{array}$ \\
\hline Dysaphis lauberti Börner & oligo & $\mathrm{L} / \mathrm{A}$ & sap sucker & $\begin{array}{l}\text { stem, umbel, } \\
\text { leaves }\end{array}$ & $\mathrm{EU} / \mathrm{CAU}$ & Hansen \& Hattendorf ${ }^{f}$ \\
\hline Dysaphis newskyi newskyi Börner & mono & $\mathrm{L} / \mathrm{A}$ & sap sucker & $\begin{array}{l}\text { stem, umbel, } \\
\text { leaves }\end{array}$ & $\mathrm{EU}^{\mathrm{OC}}$ & Heie, 1992; Hansen \& Hattendorf ${ }^{f}$ \\
\hline Paramyzus heraclei Börner & mono & $\mathrm{L} / \mathrm{A}$ & $\begin{array}{l}\text { disease transmit- } \\
\text { ter, sap sucker }\end{array}$ & leaves & $\mathrm{EU} / \mathrm{CAU}$ & $\begin{array}{l}\text { Sampson, 1990; Heie, 1994; Hansen \& } \\
\text { Hattendorf }^{\text {f }}\end{array}$ \\
\hline \multicolumn{7}{|l|}{ COLEOPTERA } \\
\hline \multicolumn{7}{|l|}{ CERAMBycidae } \\
\hline Phytoecia boeberi Ganglbauer & & A & & stem, leaves & CAU & Hansen \& Hattendorf ${ }^{\mathrm{f}}$ \\
\hline Phytoecia nigripes Voet & oligo & $\mathrm{L} / \mathrm{A}$ & $\begin{array}{l}\text { root borer, stem } \\
\text { borer, }\end{array}$ & stem, root & $\mathrm{CAU}^{\mathrm{OE}}$ & Koch, 1992; Hansen \& Hattendorf ${ }^{\mathrm{f}}$ \\
\hline \multicolumn{7}{|l|}{ Chrysomelidae } \\
\hline $\begin{array}{l}\text { Chrysochloa alpestris Schummel } \\
\text { CURCULIONIDAE }\end{array}$ & oligo & $\mathrm{L} / \mathrm{A}$ & leaf chewer & leaves & $\mathrm{EU}$ & Cagán \& Nentwig 1998 \\
\hline Calosirus apicalis Gyllenhal & oligo & $\mathrm{L} / \mathrm{A}$ & leaf chewer & leaves, root & $\mathrm{EU}$ & Koch, 1992; Jakob et al., 1998 \\
\hline Liophloeus tessulatus Müller & oligo & $\mathrm{L} / \mathrm{A}$ & $\begin{array}{l}\text { root borer, leaf } \\
\text { chewer, }\end{array}$ & $\begin{array}{l}\text { stem, leaves, } \\
\text { root }\end{array}$ & $\mathrm{EU}^{\mathrm{OC}}$ & $\begin{array}{l}\text { Bürki \& Nentwig, 1997; Cagán \& Nentwig, } \\
\text { 1998; Hansen \& Hattendorf }{ }^{\mathrm{f}}\end{array}$ \\
\hline Liophloeus lentus Germar & oligo & A & $\begin{array}{l}\text { root borer, leaf } \\
\text { chewer, }\end{array}$ & root, leaves & $\mathrm{EU}$ & Cagán \& Nentwig, 1998 \\
\hline Lixus iridis Olivier & oligo & $\mathrm{L} / \mathrm{A}$ & $\begin{array}{l}\text { stem borer, leaf } \\
\text { chewer }\end{array}$ & stem, leaves & $\mathrm{EU} / \mathrm{CAU}$ & $\begin{array}{l}\text { Cagán \& Nentwig, 1998; Hansen \& } \\
\text { Hattendorf }^{\text {f }}\end{array}$ \\
\hline Otiorhynchus tatarchani Reitter & & $\mathrm{A}$ & $\begin{array}{l}\text { root borer, leaf } \\
\text { chewer }\end{array}$ & root, leaves & CAU & Hansen \& Hattendorf ${ }^{\mathrm{f}}$ \\
\hline Nastus fausti Reitter & & $\mathrm{L} / \mathrm{A}$ & $\begin{array}{l}\text { root borer, leaf } \\
\text { chewer }\end{array}$ & $\begin{array}{l}\text { root, stem, } \\
\text { leaves }\end{array}$ & CAU & Hansen \& Hattendorf ${ }^{f}$ \\
\hline \multicolumn{7}{|l|}{ LEPIDOPTERA } \\
\hline \multicolumn{7}{|l|}{ EPERMENIIDAE } \\
\hline Epermenia chaerophyllella Goeze & oligo & $\mathrm{E} / \mathrm{L} / \mathrm{P}$ & leaf miner, & leaves & $\mathrm{EU}^{\mathrm{OC}}$ & Sampson, 1990; Emmet, 1996 \\
\hline Epermenia illigerella Hubner & oligo & $\mathrm{L} / \mathrm{P} / \mathrm{A}$ & leaf chewer & leaves & $\mathrm{EU}^{\mathrm{OC}}$ & Cagán \& Nentwig, 1998 \\
\hline Phaulernis dentella Zeller & oligo & $\mathrm{E} / \mathrm{L} / \mathrm{P}$ & chewing & umbel, leaves & $\mathrm{EU}$ & Sampson, 1990 \\
\hline \multicolumn{7}{|l|}{ Noctuidae } \\
\hline Dasypolia templi Thunberg & oligo & $\mathrm{L}$ & chewing & $\begin{array}{l}\text { root, stem, } \\
\text { umbel, leaves }\end{array}$ & $\mathrm{CAU}^{\mathrm{OE}}$ & Seppänen, 1970; Hansen \& Hattendorf ${ }^{f}$ \\
\hline \multicolumn{7}{|l|}{ DEPRESSARIIDAE } \\
\hline Depressaria radiella Goeze & oligo & $\mathrm{L} / \mathrm{P}$ & chewing & umbel & $\mathrm{EU} / \mathrm{CAU}$ & $\begin{array}{l}\text { Sampson, 1990; Bürki \& Nentwig, 1997; } \\
\text { Hansen \& Hattendorf }^{\mathrm{f}}\end{array}$ \\
\hline Agonopterix heracleana L. & oligo & $\mathrm{L}$ & $\begin{array}{l}\text { leaf roller, } \\
\text { umbel chewing }\end{array}$ & leaves & $\mathrm{EU} / \mathrm{CAU}$ & $\begin{array}{l}\text { Emmet, 1979; Sampson, 1990; Hansen \& } \\
\text { Hattendorf }^{\mathrm{f}}\end{array}$ \\
\hline $\begin{array}{l}\text { Agonopterix caucasiella Zlobin } \\
\text { (new species) }\end{array}$ & & $\mathrm{L} / \mathrm{P}$ & umbel chewing & & & Nielsen \& Ravn ${ }^{\mathrm{f}}$ \\
\hline \multicolumn{7}{|l|}{ TORTRICIDAE } \\
\hline Cydia gallicana Guenée & oligo & $\mathrm{L}$ & chewing & umbel & $\mathrm{EU}^{\mathrm{OC}}$ & Emmet, 1979; Sampson, 1990 \\
\hline
\end{tabular}




\begin{tabular}{|c|c|c|c|c|c|c|}
\hline \multicolumn{7}{|l|}{ DIPTERA } \\
\hline \multicolumn{7}{|l|}{ TEPHRITIDAE } \\
\hline Euleia heraclei L. & oligo & $\mathrm{L}$ & $\begin{array}{l}\text { leaf miner, } \\
\text { chewing }\end{array}$ & leaves & $\mathrm{EU}^{\mathrm{OC}}$ & $\begin{array}{l}\text { Sampson, 1990; Cagán \& Nentwig, 1998; } \\
\text { Hansen \& Hattendorf }^{\text {f }}\end{array}$ \\
\hline \multicolumn{7}{|l|}{ AgromyZidae } \\
\hline $\begin{array}{l}\text { Melanagromyza angeliciphaga } \\
\text { Spencer }\end{array}$ & oligo & $\mathrm{L} / \mathrm{P} / \mathrm{A}$ & stem borer & stem & $\mathrm{EU} / \mathrm{CAU}$ & $\begin{array}{l}\text { Spencer, 1972; Bürki \& Nentwig, 1997; Jakob } \\
\text { et al., 1998; Hansen \& Hattendorf }{ }^{\mathrm{f}}\end{array}$ \\
\hline $\begin{array}{l}\text { Melanagromyza heracleana Zlobin } \\
\text { (new species) }\end{array}$ & oligo & $\mathrm{L} / \mathrm{P} / \mathrm{A}$ & stem borer & stem & CAU & Hansen \& Hattendorf ${ }^{\mathrm{f}}$ \\
\hline Phytomyza spondylii Goureau & oligo & $\mathrm{L} / \mathrm{P}$ & leaf miner & leaves & $\mathrm{EU}^{\mathrm{OC}}$ & $\begin{array}{l}\text { Ashwood-Smith et al., 1984; Bürki \& Nentwig, } \\
\text { 1997; Sampson, 1990; Nielsen \& Ravn }{ }^{\mathrm{f}}\end{array}$ \\
\hline Phytomyza sphondyliivora Spencer & oligo & $\mathrm{L}$ & leaf miner & leaves & $\mathrm{EU} / \mathrm{CAU}$ & Spencer, 1972; Nielsen \& Ravnf; \\
\hline Pegomya versicolor Meigen $^{\mathrm{e}}$ & mono & $\mathrm{L}$ & leaf miner & leaves & EU & Bei-Bienko et al., 1989; Sheppard, 1991 \\
\hline \multicolumn{7}{|l|}{ CECIDOMYIIDAE } \\
\hline Contarinia heraclei Rübsaamen ${ }^{\mathrm{e}}$ & mono & $\mathrm{L}$ & chewing & leaves & EU & Bei-Bienko et al., 1989 \\
\hline Contarinia nikolayi Rübsaamen ${ }^{\mathrm{e}}$ & mono & $\mathrm{L}$ & chewing & umbel & EU & $\begin{array}{l}\text { Bei-Bienko et al., 1989; Sampson, 1990; } \\
\text { Nijveldt, } 1995\end{array}$ \\
\hline Macrolabis heraclei Kaltenbach ${ }^{\mathrm{e}}$ & mono & $\mathrm{L}$ & gall former & leaves & $\mathrm{EU}^{\mathrm{OC}}$ & Bei-Bienko et al., 1989; Nijveldt, 1995 \\
\hline \multicolumn{7}{|l|}{ Psilidae } \\
\hline Psila rosae Fabricius & oligo & $\mathrm{L}$ & root borer & root & $\mathrm{EU}^{\mathrm{OC}}$ & $\begin{array}{l}\text { Hardmann \& Ellis, 1982; Nielsen \& Ravn } \\
\text { Hansen \& Hattendorf }\end{array}$ \\
\hline
\end{tabular}

${ }^{a}$ Stages collected: $\mathrm{E}=$ eggs, $\mathrm{L}=$ larvae, $\mathrm{P}=$ pupae, $\mathrm{A}=$ adults. ${ }^{\mathrm{b}}$ mono $=$ feeds only on Heracleum spp., oligo $=$ feeds on Apiaceae, poly $=$ feeds on several plant families. ${ }^{c}$ Plant organ: umbel $=$ feeding on seeds and flower stalks but not on pollen and nectar. ${ }^{\mathrm{d}}$ Locality: The locality, where the species is found, is noted as Europe $=\mathrm{EU}$ and Caucasus $=\mathrm{CAU}$. EU/CAU = found in both regions. EU does not mean that this species is not occurring in the Caucasus, but just that it has not been found so far on $H$. mantegazzianum in the Caucasus. ${ }^{\text {OC }}=$ Occurs in Caucasus but so far not found on $H$. mantegazzianum. ${ }^{\mathrm{OE}}=$ Occurs in Europe but so far not found on H. mantegazzianum. ${ }^{\mathrm{e}}$ Found only on other Heracleum species than H. mantegazzianum. ${ }^{\mathrm{f}}$ Collected during field trips in 2002 in the Caucasus, unpubl.

scoparius). We found that the proportion of specialists was significantly dependent on whether the weed is invasive or native $(\mathrm{p}<0.001)$ (Fig. 2). The proportion was also significantly different among the four invasive weed species $(\mathrm{p}<0.001)$. Other studies make useful comparisons. The insects feeding on goldenrod Solidago altissima L., horsenettle Solanum carolinense L., and broom Cytisus scoparius L. were divided into generalists and specialists by Jobin et al. (1996, specialists are within

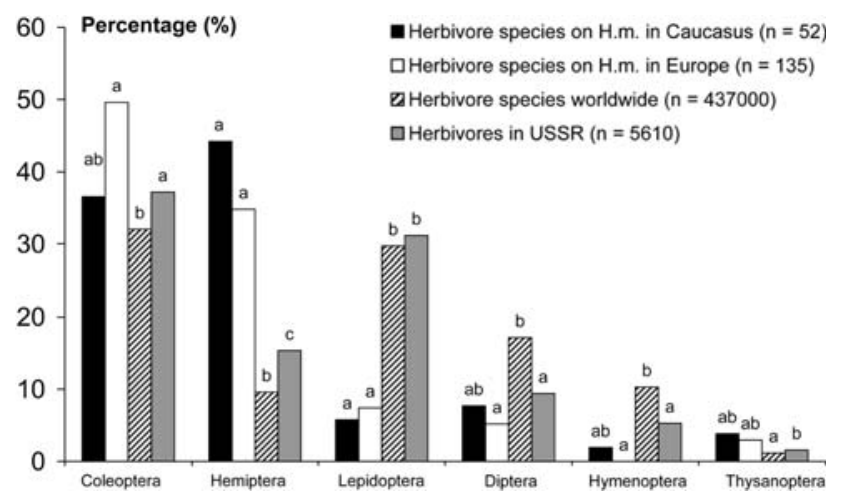

Fig. 3. Percentage of herbivores on $H$. mantegazzianum (H.m.) belonging to different insect orders. Different letters above the columns for the same insect order refer to a significant difference in a $2 \times 2$ contingency test $(p<0.05)$. Data on the worldwide number of herbivore species follow Bernays (2003); data on herbivores on beneficial plants in the former USSR are according to Kryzhanovskij (1974), Narchuk \& Tryapitzin (1981), and Kuznetzov (1999). genus, $n=276$ ), Imura (2003, specialists are within family, $\mathrm{n}=57)$ and Memmott et al. (2000, specialists within tribe Genistea, $\mathrm{n}=42$ ) respectively.

The proportions of species in each insect order found on H. mantegazzianum in the native area in the Caucasus as compared with the invaded part of Europe were not significantly different $(p>0.3)$ (Fig. 3). When we compared the number of species found in a particular order on $H$. mantegazzianum (1) with the percentage of species

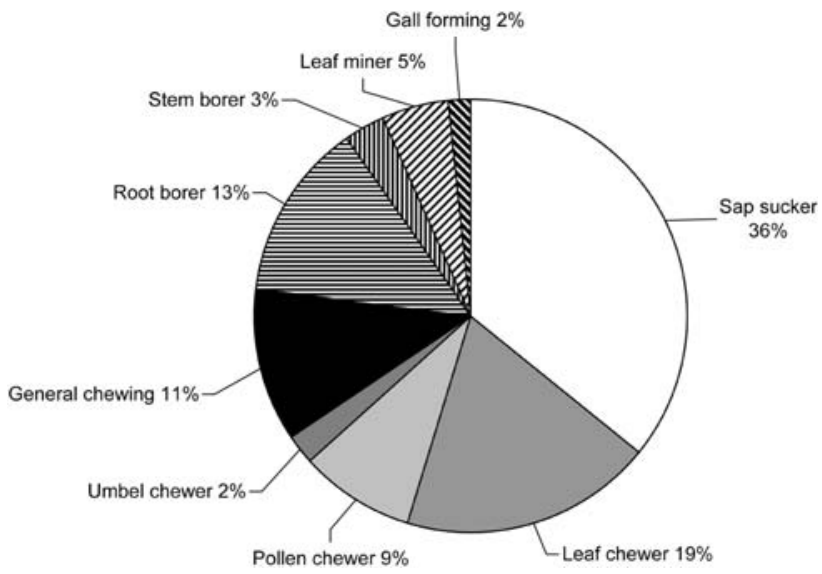

Fig. 4. The feeding habits ("guilds") of the 265 insect species found on Heracleum spp. Multiple entries were accepted becuse larvae sometimes feed on different organs than do the adults. Chewing insects are feeding on external plant organs and umbel chewers represent the insects chewing on the seeds or the flower stalks. 
TABle 2. Biomass $(\mathrm{g})$ of $78 \mathrm{H}$. mantegazzianum plants in August, in the flowering stage.

\begin{tabular}{lccccc}
\hline & Flowers & Leaves & Stem & Root & Total \\
\hline Average biomass & 369 & 354 & 1084 & 412 & 2219 \\
\hline SE & 34 & 59 & 71 & 23 & 153 \\
\hline
\end{tabular}

found worldwide (Bernays, 2003) and (2) with 5610 phytophagous insects found on beneficial plants of the former USSR (data from Kryzhanovskij, 1974; Narchuk \& Tryapitzin, 1981; Kuznetzov, 1999) (Fig. 3), then we find that sap-sucking herbivores (primarily from the Hemiptera) constitute an disproportionately large feeding guild on H. mantegazzianum (Fig. 4). This is in spite of the fact that Hemiptera comprise much less species than do Coleoptera or Lepidoptera in the former USSR and worldwide (Fig. 3). In the Caucasus and in Europe, a significantly larger proportion of species from Hemiptera is found on $H$. mantegazzianum than expected from the world species abundance $(\mathrm{p}<0.0001)$. The proportion of lepidopteran species is significantly lower on $H$. mantegazzianum in Europe and in the Caucasus than worldwide $(\mathrm{p}<0.023)$ or in the former USSR $(\mathrm{p}<0.016)$. Diptera and Hymenoptera are significantly less represented in Western Europe on $H$. mantegazzianum than expected from their worldwide distribution ( $\mathrm{p}<0.013$ and $\mathrm{p}<0.003)$, but not less represented when in comparison with the former USSR (Fig. 3). In contrast Diptera and Hymenoptera in the Caucasus match the expected distribution worldwide and in the former USSR ( $p>0.07$ ) (Fig. 3). The chewers feeding on different plant organs mainly belong to Coleoptera and constitute another large feeding guild (41\%) (Fig. 4). The root borers are also coleopterans. Gallforming insects predominantly belong to the Cecidomyiidae, and they produce galls in the leaves and the umbel,

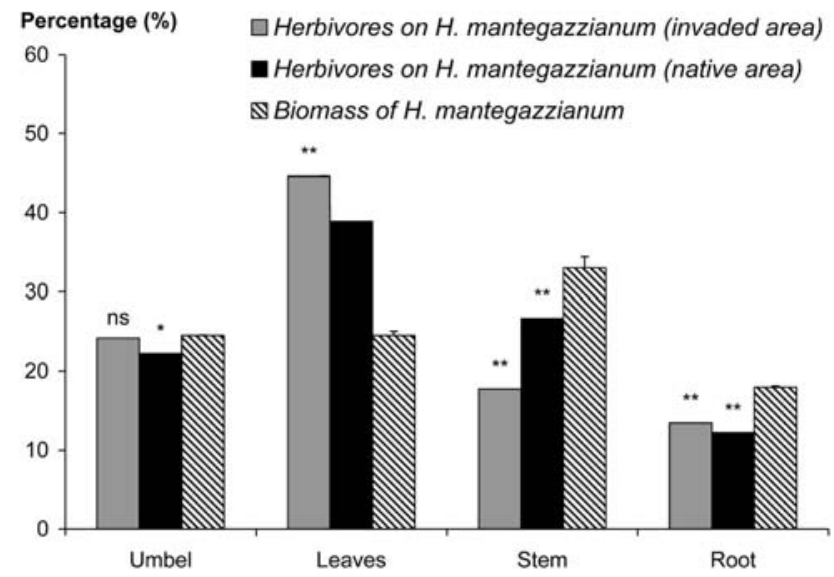

Fig. 5. The percentage of insect species belonging to each plant feeding niche in Europe and in the Caucasus is compared with the relative biomass $\pm \mathrm{SE}$ of these plant organs (relative niche size) (Table 2). No significant difference is found between the proportions of insect species on $H$. mantegazzianum in the native areas $(\mathrm{n}=53)$ compared with the invaded areas $(\mathrm{n}=$ 133). An asterisk indicates a significant difference between proportion of species and the proportion of biomass belonging to the particular plant organ (ns = not significant). whereas leaf miners chiefly involve other Diptera (Fig. 4).

Relatively few species are associated with stem and roots of $H$. mantegazzianum, given their large size (biomass) (Fig. 5) $(\mathrm{p}<0.001)$. In contrast, significantly more species were found on the leaves compared with their relative biomass in July and August $(\mathrm{p}<0.001)$. The total biomass \pm SE of the different organs on the flowering plant in August was $2.22 \pm 0.15 \mathrm{~kg}$ (Table 2). The proportion of 162 herbivorous species found in leaves, umbels, stems, and roots are, however, not significantly different when the Caucasus is compared with Europe ( $p$ $=0.30)$ (Fig. 5).

\section{DISCUSSION}

\section{Characteristics of the herbivore community}

Strong et al. (1984) reasoned that herbivores from the pool of native species present in any region rapidly and asymptotically accumulate on introduced plants. The first insects to colonize a new host plant are polyphagous herbivores. Further, a low proportion of endophages is also considered to be characteristic for young herbivore assemblages on introduced plant species, since they need to be better adapted to the chemistry and structure of the plant (Strong et al., 1984; Frenzel \& Brandl, 1998). We found a higher proportion of specialized monophagous and oligophagous species in the Caucasus area compared with the invaded European countries. The same patterns have been observed on other invasive plants (Jobin et al., 1996; Memmott et al., 2000; Imura, 2003). The enemy release hypothesis predicts that a larger proportion of specialists and/or a higher density or biomass of herbivores should be found in the native Caucasus area, where they would inflict more damage to the host plant. Our investigation nicely supports the first prediction and therefore endorses one aspect of both the enemy release hypothesis (ERH) and the evolution of increased competitive ability hypothesis (EICA). The present data cannot identify whether the herbivore biomass is higher also, which was in fact the case in the study by Memmott et al. (2000). Hattendorf (2005) demonstrated that the defence systems (furanocoumarins and trichomes) of giant hogweeds are developed to different degrees in the native and invaded regions. Indirectly, this indicates that the composition of herbivore species or herbivore biomass on $H$. mantegazzianum is different in the two regions. These results support the EICA hypothesis.

There is a high number of sap-sucking species on $H$. mantegazzianum (Fig. 4) and hemipterans are overrepresented in the invaded region when it is compared with the native region (Fig. 3). This over-representation and an under-representation of Lepidoptera and Diptera have also been found in comparable studies (Imura, 2003; Simberloff, 2003). There are various ways in which overand under-representations of some insect orders may have developed. Some insect groups are known to contain more generalist feeders, which could be responsible for the observed differences. Another explanation could be that certain plant defence systems (e.g. furanocoumarins) 
are particularly active against certain herbivore insect orders on $H$. mantegazzianum. A third explanation is that the evolutionary adaptation and speciation of herbivores, on the relatively recently evolved genus Heracleum, is happening faster in some insect order than in others.

\section{Feeding specificity}

One aim of this study was to evaluate the phytophagous insect species feeding on $H$. mantegazzianum in native and invaded areas. We found very few additional species during the last surveys, and considering the extensive insect collections we made and the large part of the distribution range of giant hogweed we covered, it is realistic to assume that we have recorded most herbivore species. In the Caucasus we did not find any insects feeding exclusively on $H$. mantegazzianum (Table 1) and this result could be called disappointing. Data from the literature, in general, tend to assign too many host plants to herbivores, since they sometimes also include plants where the insects may sit but not feed, or they include plants on which the herbivores occasionally feed but are not able to reproduce. Additionally, in the Caucasus we found several herbivores with unknown host specificity [Nastus fausti, Phytoecia boeberi, Otiorhynchus tartarchani, Melanagromyza heracleana (new species) and Agonopterix caucasiella (new species)]. Since some other species in these genera are known to be monophagous, they could represent potential agents for biocontrol. Such an herbivore may become a suitable biocontrol agent if it has an overall negative effect on the fitness of the plant. If the impact of a particular species was only weak in the Caucasus, this may be caused by the predators or parasites of candidate species, thus, preventing a larger impact on H. mantegazzianum. Since the ERH takes this into consideration and predicts a larger impact of the particular species in the invaded area, it could become a promising candidate. In this case, the next step would include the required tests to analyse host range according to international standards (OECD, 2004).

\section{Niche sizes}

The biomass of the plant organs of $H$. mantegazzianum is considered as a representation of the relative available niche space (Table 2). These niches were not equally occupied (Fig. 5). Umbels have seeds with a high nutritional value and are an exposed plant organ, which would favour a high herbivore load (Lawton \& Schroeder, 1977). However, umbels and seeds have a high furanocoumarin content (Berenbaum, 1981) and are only available during a rather short period during the 3 or more years of lifespan of giant hogweed. Both these factor favour a smaller herbivore number (Frenzel \& Brandl, 1998). The root represents a long-living organ important for the plant. It should therefore be well defended (e.g. by chemical defence). Fig. 5 shows that root and stem comprise a large proportion of the $H$. mantegazzianum biomass, but we found only a few species feeding on it. Stems contain large amounts of structural compounds giving a lower nutritional value and the observed low number of species on the stem supports this idea. Leaves, on the other hand, are easily accessible and digestible, and this is probably the reason why a significantly higher proportion of species is found on the leaves. These results show that the number of herbivores is not completely predicted by niche space but, as we expected, niche occupancy can best be explained by its accessibility, chemical defence and digestibility. It would be interesting to analyse if similar patterns can be observed in other weeds. In Europe and in the Caucasus, we never observed high herbivore densities that were sufficient to kill a plant and we interpret this to be a result of an effective plant defence and/or intensive herbivore regulation.

ACKNOWLEDGEMENTS. This project had been funded by the EU (5th FW) / Switzerland (BBW: EVK2-CT-2001-00128). M. Erneberg, Danish Forest and Landscape Research Institute, Hørsholm Denmark arranged herbivore collections and insect identifications in Denmark. L. Cagán, Department of Plant Protection, Slovak Agricultural University in Nitra, Slovakia, provided a list of collected herbivores from Slovakia and an extended literature survey. N. Erlykova and co-workers from the Zoological Institute, Russian Academy of Science (St. Petersburg), made a part of the insect collections in the Russian Caucasus, literature survey and insect identifications. Thanks to The Natural History Museum of London, Department of Entomology, England for the identification of species, to C. Klingler for checking the manuscript, and three anonymous reviewers for valuable comments.

\section{REFERENCES}

Ashwood-Smith M.J., Ring R.A., Liu M., Phillips S. \& Wilson M. 1984: Furanocoumarin resistance in the larvae of Phytomyza spondylii (Diptera: Agromyzidae) feeding on Heracleum lanatum is associated with the enzymatic breakdown of 8-methoxypsoralen. Can. J. Zool. 62: 1971-1976.

Bei-Bienko G.Y., Steyskal G.C., Sharma B.R. \& Kotekar V.S. 1989: Keys to the Insects of the European Part of the USSR. Vol. V (A and B), Part I. Diptera and Siphonaptera. E.J. Brill, Leiden, $1233 \mathrm{pp}$.

Berenbaum M. 1981: Patterns of furanocoumarin distribution and insect herbivory in the Umbelliferae: Plant chemistry and community structure. Ecology 62: 1254-1266.

Berenbaum M. \& FeEny P. 1981: Toxicity of angular furanocoumarins to swallowtail butterflies: Escalation in a coevolutionary arms race? Science 212: 927-929.

Bernays E.A. 2003: Phytophagous insects. In Resh V.H. \& Cardé R.T. (eds): Encyclopedia of Insects. Academic Press, Elsevier Science, pp. 902-905.

Blossey B. \& Nötzold R. 1995: Evolution of increased competitive ability in invasive non-indigenous plants: A hypothesis. J. Ecol. 83: 887-889.

BÜRKI C. \& Nentwig W. 1997: Comparison of herbivore insect communities of Heracleum sphondylium and H. mantegazzianum in Switzerland (Spermatophyta: Apiaceae). Entomol. Gen. 22: 147-155.

CAgÁN L. \& Nentwig W. 1998: Insect herbivores on giant hogweed, Heracleum mantegazzianum Somm. et Levier - a first step towards a biological control programme. Review and report about the research in 1996-1997. Nitra, 88 pp.

Colautti R.I. \& MacIsaAc H.J. 2004: A neutral terminology to define "invasive" species. Diversity Distrib. 10: 135-141.

Colautti R.I., Ricciardi A., Grigorovich I.A. \& Macisaac H.J. 2004: Is invasion success explained by the enemy release hypothesis? Ecol. Letters 7: 721-733. 
Emmet A.M. 1979: A Field Guide to the Smaller British Lepidoptera. British Entomological and Natural History Society, London, $288 \mathrm{pp}$.

Eмmeт A.M. 1996: The Moths and Butterflies of Great Britain and Ireland. Vol. 3. Yponomeutidae - Elachistidae. Harley Books, Colchester, $452 \mathrm{pp}$.

Frenzel M. \& BRANDL R. 1998: Diversity and composition of phytophagous insect guilds on Brassicaceae. Oecologia 113: 391-399.

Grace J. \& Nelson M. 1981: Insects and their pollen loads in a hybrid Heracleum site. New Phytol. 87: 413-423.

HANSEN S.O. 2005: Interactions between the Invasive Weed Heracleum mantegazzianum and Associated Insects. Ph.D. thesis, University of Bern, Switzerland, $111 \mathrm{pp}$.

HaRdMan J.A. \& Ellis P.R. 1982: An investigation of the host range of the carrot fly, Psila rosae. Ann. Appl. Biol. 100: 1-9.

HatTENDORF J. 2005: Impact of Endophagous Herbivores on the Invasive Weed Heracleum mantegazzianum and Associated Interactions. PhD thesis. University of Bern, Switzerland, 96 pp.

HeIE O.E. 1992: The Aphidoidea (Hemiptera) of Fennoscandia and Denmark. IV. Family Aphididae. Part 1. Tribe Macrosiphini, Subfamily Aphidinae. Fauna Entomologica Scandinavica. Vol. 25. E.J. Brill/Scandinavian Science Press, Leiden, $217 \mathrm{pp}$.

HeIE O.E. 1994: The Aphidoidea (Hemiptera) of Fennoscandia and Denmark. V. Family Aphididae. Part 2. Tribe Macrosiphini, Subfamily Aphidinae. Fauna Entomologica Scandinavica. Vol. 28. E.J. Brill/Scandinavian Science Press, Leiden, $239 \mathrm{pp}$.

Holman J. 1991: Aphids (Homoptera, Aphidoidea) and their host plants in the botanical garden of Charles University in Prague. Acta Univ. Carol. (Biol.) 35: 19-55.

Howell J.F. \& Games P.A. 1974: The effects of variance heterogeneity on simultaneous multiple-comparison procedures with equal sample size. Br. J. Math. Stat. Psy. 27: 72-81.

IMURA O. 2003: Herbivorous arthropod community of an alien weed Solanum carolinense L. Appl. Entomol. Zool. 38: 293-300.

JaKob B., Mandach T.V. \& Nentwig W. 1998: Phytophage an Heracleum mantegazzianum und Heracleum sphondylium. $Z$. Pflanzenk. Pflanzenschutz. 16: 223-230.

Jobin A., Schaffner U. \& Nentwig W. 1996: The structure of the phytophagous fauna on the introduced weed Solidago altissima in Switzerland. Entomol. Exp. Appl. 79: 33-42.

Keane R.M. \& Crawley M.J. 2002: Exotic plant invasions and the enemy release hypothesis. Trends Ecol. Evol. 17: $164-170$.

KNUDSEN E.A. 1983: Seasonal variation in the content of phototoxic compounds in giant hogweed. Contact Dermatitis 9: 281-284.

Косн K. 1992: Die Käfer Mitteleuropas. Ökologie. Vol. 3. Goecke and Evers, Krefeld, 389 pp.

KryzhanovskiI O.L. (ed.) 1974: Insects and Mites - Pests of Agricultural Plants. Vol. 2. Coleoptera. Nauka, Leningrad, 335 pp. [in Russian].

KryzhanovskiI O.L. \& Dantsig E.M. (eds) 1972: Insects and Mites - Pests of Agricultural Plants. Vol. 1. Insects with Hemimetabolous Development. Nauka, Leningrad, 323 pp. (in Russian).

KuZnetsov V.I. (ed.) 1994: Insects and Mites - Pests of Agricultural Plants. Vol. 3(1). Lepidoptera. Nauka, St. Petersburg, 333 pp. [in Russian].

KuzneTsov V.I. (ed.) 1999: Insects and Mites - Pests of Agricultural Plants. Vol. 3(2). Lepidoptera. Nauka, St. Petersburg, 407 pp. [in Russian].
LAWTON J.H. 1976: The structure of the arthropod community on bracken. Bot. J. Linn. Soc. 73: 187-216.

Lawton L.H. \& Schroeder D. 1977: Effects of plant type, size of geographical range and taxonomic isolation on number of insect species associated with British plants. Nature 265: 137-140.

Memmott J., Fowler S.V., Paynter Q., Sheppard A.W. \& Syrett P. 2000: The invertebrate fauna on broom, Cytisus scoparius, in two native and two exotic habitats. Acta Oecol. 21: 213-222.

MÜller-Schärer H., Schaffner U. \& Steinger T. 2004: Evolution in invasive plants: implications for biological control. Trends Ecol. Evol. 19: 417-422

Mitchell C.E. \& Power A.G. 2003: Release of invasive plants from fungal and viral pathogens. Nature 421: 625-628.

Mandenova I.P. 1950: Caucasian Species of the Genus Heracleum. Systematics and Plant Geography Monographs, Ser. A. Akademia Nauk Gruzinskoy SSR, Tbilisi, 104 pp. [in Russian].

NarchuK E.P. \& TRYAPITSIN V.A. (eds) 1981: Insects and Mites - Pests of Agricultural Plants. Vol. 4. Hymenoptera and Diptera. Nauka, Leningrad, $221 \mathrm{pp}$. [in Russian].

Nentwig W., Bacher S., Beierkuhnlein C., Brandl R. \& GrabHERR G. 2004: Ökologie. Spektrum, Heidelberg, 466 pp.

NiJveldt W. 1995: Gall Midges of Economic Importance. Vol. VIII. Gall Midges - Miscellaneous. Crosby Lockwood, London, $221 \mathrm{pp}$

OECD 2004: Guidance for Information Requirements for Regulation of Invertebrates as Biological Control Agents (IBCAs). Series on Pesticides, No. 21. www.oecd.org/dataoecd/6/20/ 28725175.pdf

Otte A. \& Franke R. 1998: The ecology of the Caucasian herbaceous perennial Heracleum mantegazzianum Somm. et Lev. (giant hogweed) in cultural ecosystems of Central Europe. Phytocoenologia. 28: 205-232.

PYŠEK P. 1994: Ecological aspects of invasion by Heracleum mantegazzianum in the Czech Republic. In de Waal L.C., Child E.L., Wade P.M. \& Brock J.H. (eds): Ecology and Management of Invasive Riverside Plants. Wiley and Sons, Chichester, pp. 45-54.

PYŠEK P. \& PYŠEK A. 1995: Invasion by Heracleum mantegazzianum in different habitats in the Czech Republic. J. Veg. Sci. 6: $711-718$.

Sampson C. 1990: Towards Biological Control of Heracleum mantegazianum (Giant Hogweed), Umbelliferae. Master thesis, Imperial College of Science, University of London.

SCHEPKER H. \& KowARIK I. 2001: Control of non-native plants and its success in Niedersachsen (Northern Germany). In Kowarik I. \& Starfinger U. (eds): Biological Invasions in Germany. A Challenge to Act? BfN Scripten 32. Bonn, pp. 61-62.

SEPPÄNEn E.J. 1970: Suurperhostoukkien Ravintokasvit. [The Food-plants of the Larvae of the Macrolepidoptera of Finland.] Suomen Eläimet - Animalia Fennica 14. Werner Söderström Osakeyhtiö, 179 pp. [in Finnish].

Sheppard A.W. 1991: Biological flora of the British Isles. No. 171. Heracleum spondylium. Ecology 79: 235-258.

SimberLoff D. 2003: Introduced insects. In Resh V.H. \& Cardé R.T. (eds): Encyclopedia of Insects. Academic Press, Elsevier Science, pp. 597-602.

Spencer K.A. 1972: Diptera: Agromyzidae. Handbooks for the Identification of British Insects. Vol. 10. Royal Entomological Society, London, 136 pp.

Strong D.R., Lawton J.H. \& Southwood R. 1984: Insects on Plants, Community Patterns and Mechanisms. Harvard University Press, Cambridge, MA, 313 pp. 
Torchin M.E., Lafferty K.D. \& KurIs A.M. 2001: Release from parasites as natural enemies: Increased performance of a globally introduced marine crab. Biol. Invas. 3: 333-345.

WAGNer E. 1966: Wanzen oder Heteropteren. In Dahl M. \& Peus F. (eds): Pentatomorpha. Die Tierwelt Deutschlands und der angrenzenden Meeresteile. Vol. 54. Fischer, Jena, 235 pp.
WoLfE L.M. 2002: Why alien invaders succeed: support for the escape-from-enemy hypothesis. Am. Nat. 160: 705-711.

Received June 10, 2005; revised and accepted October 6, 2005 